\title{
MANAGING THE COVID-19 \\ CRISIS IN A DIVIDED BELGIAN FEDERATION
}

\section{Cooperation against all odds}

\section{Patricia Popelier and Peter Bursens}

\subsection{Introduction}

When it recorded its first case of Covid-19 on 3 February 2020, Belgium was in the midst of a political crisis. Since the fall of its government in December 2018 and elections in May 2019, political parties had still not succeeded in forming a new federal government. The antagonism between the two major parties, the Flemish nationalist Nieuw-Vlaamse Alliantie and the francophone social democratic Parti Socialiste, was intensified by the elections, which resulted in deepened division between Flemish and Walloon voters and an unprecedented rise of extremist parties on either side of the spectrum. Meanwhile, a caretaker minority government stayed on, backed by temporary parliamentary support, until a new government was formed eventually on 1 October 2020, now backed by a parliamentary majority of seven parties - a transition that took place at a moment when infections were on the rise again.

This chapter examines how a divided Belgian federation responded to the Covid-19 pandemic, with the period of analysis extending from February to October 2020 and thus covering the full cycle of the first wave - including the outbreak in February, the peak in spring, and the low point in summer - and the beginning of a second outbreak at the end of summer. The shift from the first to the second wave coincided with the start of a new federal government, a turn of affairs that was accompanied by some changes of response, among them to the approach taken to intergovernmental relations (IGR).

With a population of 11.5 million, Belgium is a relatively small country, but it is deeply divided along converging cleavages between the north (Dutchspeaking, prosperous, and voting predominantly centre-right) and the south (French-speaking, less prosperous, and voting predominantly left). To accommodate these tensions, the country transformed itself over three decades from a 
unitary, decentralised state into a dyadic federation with confederal traits; subsequent reforms decentralised it further.

Belgium thus consists of six overlapping federated entities: three communities with language- and culture-related competences (Flemish, French, and German) and three regions (Flemish, Walloon, and Brussels) with economicand territory-based competences. However, politics revolves around the two major (French-speaking and Dutch-speaking) linguistic communities. When the Covid-19 crisis hit Belgium, even the French-speaking press, hitherto centralist in spirit, agreed that the country was split into two separate democracies. ${ }^{1}$

Public concern in Belgium about the coronavirus mounted during the spring break at the end of February when Covid-19 case numbers began to rise dramatically, especially in the north of Italy, where many Belgians go skiing; as they returned from their travels, so the number of domestic infections increased. It was nevertheless only on 13 March 2020, two days after Covid-19 claimed its first fatality in Belgium, that the federal government initiated health measures, following which a more drastic lockdown was imposed on 18 March.

By mid-April, at the height of the crisis, Belgium was at the top of the list of Covid-19 deaths per capita worldwide, with a fatality rate of 359 per million residents. ${ }^{2}$ Unlike those of other countries, its statistics included fatalities - mostly in elderly homes - that were probably caused by Covid-19 but not officially confirmed as such (Wilmès 2020: 5). Still, the coronavirus undoubtedly hit hard in Belgium. The country's high population density, its open economy at Europe's crossroads, and the return of tourists from heavily infected areas in the Italian, Austrian and French Alps, help to explain this fact.

In April, reports emerged that the economy was beginning to stagnate due to the pandemic, and in May, Belgium announced its first exit measures from the nationwide lockdown. Others followed in quick succession, until the signs of a second outbreak came to notice at the end of July. Further relaxation measures were put on hold, and new restrictions were introduced, or older ones reinstated. However, in September, schools were able to reopen for the new school year, albeit under tight conditions. At that point in the year, the government decided, in spite of a rising number of infections, not to impose stricter measures but to relax contact arrangements again in order to keep citizens motivated.

As Belgium has a high-performing health-care system, the maximum capacity of its hospitals was never exhausted. The main problem lay in the area of prevention: it had no strategic supply of face masks and lacked testing capacity. Consequently, and despite a travel ban, the virus spread quickly in elderly homes and residential care centres. Many of the subject-matter domains relevant to the crisis were competences of the federated communities, but there was immediate and widespread consensus that, for the country to fight Covid-19, the federal government had to take the lead.

At first, no distinction was made between regions, in that public data did not specify the location of infections and hospitalisations. This changed at the start of the second wave of the pandemic, when a ministerial decree ordered local 
authorities to determine in which shopping streets it would be mandatory to wear face masks, and also empowered them to take additional preventative measures (Ministerial Decree of 24 July 2020, article 13). Local governments, until then subordinate implementers of central policy, now came to the fore.

In the sections that follow, this chapter explains the Belgian system of power allocation and IGR and provides an overview of government action at the federal, federated, and local levels of authority. This will reveal three important findings. First, Covid-19 - perhaps temporarily - turned dual federalism into cooperative federalism, with the federal government occupying a prominent position in intergovernmental decision-making. Secondly, the local level of authority popped up as a relevant actor that should be factored into the design of future systems of pandemic crisis management. Thirdly, calls in Belgium for institutional reform should keep in mind that, whatever the result of such reform, it is crucial to provide clarity in the allocation of competences and to develop a scheme for more efficient intergovernmental coordination and cooperation, especially in the case of pandemics.

\subsection{The federal constitutional and legislative framework}

\subsubsection{The allocation of competences}

Belgium follows a model of dual federalism, with an allocation system based on exclusivity. This means that, as a rule, matters lie within the legislative and administrative competence of the federal authorities, the communities, or the regions, to the exclusion of the other entities. A side effect of exclusivity is fragmentation: if the federal government loses control over transferred matters and is not able to intervene in the general interest or secure inter-regional solidarity, it is inclined to transfer only parts of the matter and set restrictions on its use (Popelier 2021a). This entails that parts of a policy field are attributed to the federated entities, whereas others remain within the ambit of central powers, making it difficult to develop coherent and encompassing policies without cooperation among entities (Happaerts et al. 2012: 444). It also means that competences are formulated in a detailed way, with specific conditions and exceptions. ${ }^{3}$

Several of the matters related to preventing and containing Covid-19 were transferred to the communities, albeit with many exceptions. Together, there are four categories of community competences: person-related competences and competences in education, culture, and languages. Each is discussed below.

In terms of the Special Majority Law on the Reform of Institutions, health care, including residential-care institutions, is a community matter that falls under the category of person-related competences (article 5, section 1, I). However, in the development of this law, only specific aspects of health care were transferred to the communities, and even those aspects contained several exceptions that remained federal. For example, organic laws and financial laws on hospitals remain federal, as do basic and financial rules pertaining to medical institutions as well as to health and disability insurance. Also, only the federal 
government can impose an obligation to vaccinate. By contrast, promoting and providing vaccinations and taking quarantining and contact tracing measures are (mostly) community matters, whereas the federal government has the power to issue basic rules, for example with regard to the right to privacy. ${ }^{4}$ In addition, the communities have the power to issue preventative regulations only for specific matters and institutions, while general rules remained a federal competence. A number of social-welfare community competences are closely associated with health care, including child care, family care, and elderly care.

Education is the sole competence that was transferred in its entirety by the Constitution itself, barring only three exceptions: determining the beginning and end of compulsory schooling, setting minimum standards for granting diplomas, and administering the teachers' pension scheme; the latter all remained federal competences (Constitution, article 127, sections 1, 2). Finally, cultural competences - applying to areas such as youth policy, libraries, museums, fine arts, and sports and leisure activities (Special Majority Law on the Reform of Institutions, article 4) - were transferred to the communities, mostly without specific exceptions.

Preventative measures that impact on business operations and labour conditions, such as the closure of shops and promotion of telework, are federal matters. In turn, measures to mitigate the economic consequences of pandemic response fall under both federal and regional competences. Economic affairs such as tourism and commercial rentals are a regional competence, but many of their aspects remain federal, such as financial policy, commercial law, labour law, and social security (Special Majority Law on the Reform of Institutions, article 6, section 1, VI). As a result, during the 2020 pandemic, different subsidy mechanisms were developed at the federal and regional level. Preventative measures in response to Covid-19 also affected other regional competences, such as public transport.

Finally, at supranational level, the European Union (EU) limited Belgian authorities' discretion in combating the Covid-19 pandemic. For example, the regulation of medicines remains a residual federal competence but is controlled mostly at the EU level. Also, the principles of free movement prohibit border control and closure, except in the case of serious threat and for a limited period of time. On that basis, the federal government, by ministerial decree, closed the country's borders on 20 March 2020 (Vanheule 2020: 1448). Further restrictions arose from coordinated action by the European Council; the European Commission also engaged in coordination efforts, in its case ones that were directed, for instance, at public procurement of protective gear and at repatriating EU citizens from countries throughout the world.

\subsubsection{The absence of an emergency clause}

Belgium is a dual federation, which means that the federal and federated jurisdictions are conceived as separate entities with exclusive powers and on an equal footing; by implication, the federal government has no overriding powers. 
Fittingly, the Constitution does not even mention a state of emergency, conventionally the occasion for centralisation of power in the national executive branch - an emergency situation is only implied where it provides that it is the King who declares the existence of a state of war (article 167, section 1). The federal government does have residual powers, but these must respect the constitutional allocation of powers.

This raises the question of whether the federal government may invoke police powers to encroach upon federated policy domains, for example when closing schools and museums, prohibiting cultural and sports events, or deciding under which conditions such organisations and activities can resume. One could argue that crisis management in the case of a pandemic is inherently part of the government's residual emergency powers, given that the risk of infection threatens the entire country, which though small is densely populated.

However, the Council of State, the supreme administrative court in Belgium, warned on various occasions that the federal government does not have the exclusive residual competence to take all urgent matters but that each government is instead responsible within its own field of competences. ${ }^{5}$ Its suggestion that a cooperation agreement or explicit legal solution be adopted was not acted upon, though. Indeed, one could argue equally that because sources of infection are concentrated in specific regions, a differentiated approach is what is called for, and that police powers are inherent to the executive office at all tiers of government.

\subsection{Preparedness for a national disaster: The institutional framework}

Following an EU Decision, member states are under a duty to communicate information to the EU network operated by the European Centre for Disease Prevention and Control (ECDC) (EU Decision 2013). To this end, ${ }^{6}$ a Protocol was concluded between the federal government and the communities to establish a National Focal Point. ${ }^{7}$

The same Protocol also established a Risk Management Group (RMG) and a Risk Assessment Group (RAG). The first is composed of representatives from the federal and subnational ministries of health and decides on notification and control measures. The second is an advisory body composed of experts from the health authorities and epidemiologists of the Belgian Institute for Health (Sciensano), along with medical scientists from universities on both sides of the language divide, who are invited ad hoc to the body. The RAG takes care of the daily surveillance of potential health threats and prepares risk assessments. The politically responsible body is the Inter-ministerial Conference on Public Health, composed of the ministers responsible for public health at the federal and community levels; the coordinating crisis manager is appointed by the federal government. It is, however, up to each entity to implement the decisions within its respective range of competences (Protocol 2018, article 6, section 1). 


\subsection{Rolling out measures to contain the pandemic}

\subsubsection{Taking the initiative}

As mentioned, the Covid-19 health crisis struck Belgium in the middle of a political crisis. Given the dual nature of Belgian federalism and the extensive powers communities have in health policy, one would have expected them to take the initiative in response to the pandemic. Nonetheless, there seemed to be wide consensus that - in consultation with the communities and regions - it was the federal government that had to take the lead.

The most visible body during the first wave of infection was the National Security Council (NSC), the composition of which reflects that it was established with terrorism threats in mind. It consists of the Prime Minister, the ministers of justice, defence, home affairs and foreign affairs, the vice-ministers, and other ministers in matters under their competence (Royal Decree of 28 January 2015), in this case the Minister of Health. To deal with the Covid-19 pandemic, the NSC was extended to the regional minister-presidents. It was supported by the National Crisis Centre, which has three monitoring and advisory bodies: the RAG, the RMG, and the Scientific Committee Coronavirus. These bodies report to an Evaluation Cell (CELEVAL) consisting of representatives of health administrations and advisory bodies at national and subnational levels; in turn, CELEVAL reports to the different governments.

The NSC convened for the first time on 10 and 12 March 2020. On 13 March, the federal phase of the coordination of Belgium's pandemic response was announced and the first measures taken: cultural, social, festive, sports, and youth activities as well as religious services were prohibited; cultural, festive, recreation, and sports establishments as well as bars and restaurants were closed; and non-food stores were closed on weekends (Ministerial Decrees of 13 March 2020). Only four days later, several political parties, still unable to form a government, agreed to give the minority government of Sophie Wilmès full powers, with the promise to request a new vote of confidence after six months (Royal Decree of 17 March 2020).

Then, on 27 March, the government received special powers to take measures to address the crisis and mitigate its consequences, if need be by passing Acts of Parliament (Laws I and II of 27 March 2020 authorising the King to take measures to combat the spread of the coronavirus (Covid-19)), albeit with several formal and informal guarantees. For example, special power decrees have to be ratified by Parliament within one year, in addition to which 10 political parties acted as watchdogs in weekly meetings to discuss the Covid-19 decrees.

In the end, these special powers have not been used for preventative measures. They were taken by ministerial decree, even though their constitutionality was doubtful (Popelier 2020a, 2020b). On 18 March, the Minister of Internal Affairs decreed a more severe lockdown, one that included the closure of schools, further restrictions on shops, and a ban on travelling abroad other than for essential purposes (Ministerial Decree of 18 March 2020). 
CELEVAL was replaced on 6 April by a multidisciplinary expert group, the Group of Experts in Charge of the Exit Strategy (GEES), consisting of medical, economic, statistical, legal, and financial experts and tasked with developing an exit strategy from Belgium's initial lockdown. At the start of a second wave of infections, GEES was replaced by CELEVAL, the membership of which was broadened and included representatives of scientific research institutes, business, and the event sector, as well as medical, psychology, and health economics experts.

Political parties in power at both the regional and federal level, aware of the need for urgency, seemed to agree that the federal government has a residual power in regard to health crisis management; it was less clear, though, on how far this power extends. For example, the federal government started a programme for contact tracing but had to leave it to the communities once the Council of State made it clear that this competence (mostly) remained with the communities. ${ }^{8}$ In another example, protective masks and equipment were simultaneously procured at several levels of government, with major issues arising in mid-April 2020 about quality requirements for materials and the use of testing kits. The responsible federal minister himself complained about 'absurd' situations regarding competences and coordination (Andries 2020).

Either way, the proportionality (or loyalty) principle demands that measures cannot make it impossible or arduous for other entities to pursue their policies unless these entities are involved in the decision-making. This means that regardless of who has the final say in which matter, governments are forced to cooperate. In practice, political actors in 2020 chose to allow the federal government to take the lead, but communities and regions could implement the measures according to their competences. This sometimes led to awkward results as when, for example, a federal ministerial decree stated that communities should plan for a resumption of teaching activities on the basis of expert advice (Ministerial Decree of 15 May 2020, article 4): even though it was undisputed that emergency measures should rely on expert advice, it was not for the federal minister to impose procedural requirements.

In a third phase of pandemic governance, a differentiated approach was taken after all, one that hence brought local entities to the fore. Mayors and provincial governors have police powers of their own, but in March 2020 a ministerial decree announced the federal phase of the coordination of the coronavirus crisis (Ministerial Decree of 13 March 2020a), a regime in terms of which local entities were to be merely implementers of federal and federated decisions.

In July, however, more detailed information was made available as to where exactly new outbreaks were situated. A ministerial decree that ordered face masks to be worn in specific places, including in shopping streets, required that mayors delineate those streets; it also allowed mayors and provincial governors to take 'complementing' and, where necessary, 'additional' measures.

On this basis, the provincial governor of severely hit Antwerp province made it compulsory to wear face masks in public and imposed a (controversial) nightly 
curfew (Ordinance of 29 July of the Governor of the Province of Antwerp). In addition, the Flemish government, when its own system proved inadequate, reluctantly permitted local entities to develop their own system of contact tracing.

The discussion above presented the chronology of the measures taken. In the following sections, we dig deeper into the type of measures taken by the different government levels and then turn to IGR. Federal actions were taken mostly by the government - the federal parliament remained largely absent. Also, whenever a ministerial decree touched upon the powers of the federated entities, the executives of the regions and communities took care of the implementation without much involvement from the respective parliaments. This was the trend particularly in the French Community and the Walloon and Brussels regions.

\subsubsection{Federal action}

At the federal level, five types of measures were taken: (1) preventative, (2) health care, (3) exit, (4) socio-economic, and (5) measures to mitigate other measures. Several measures were challenged in the Council of State.

\subsubsection{Preventative measures}

Preventative measures to contain the spread of the virus in 2020 came in two waves. In the first wave, shops were closed, with some exceptions for essential services such as food shops and pharmacies; firms were ordered to close or switch to teleworking; bars and restaurants were closed (except for takeaways); school, cultural, sports, recreation, and social establishments were closed and (almost) all activities forbidden; people were ordered to stay at home except for essential activities (including walks); and travel abroad was forbidden.

These decisions were taken after long negotiations, with Flemish politicians preferring the Dutch approach that gave more consideration to economic activities, and French-speaking politicians leaning more towards the French approach which prioritised public health. In the end, all parties agreed on a drastic lockdown, even if this intruded in subnational domains. For example, although Flemish political parties preferred to keep schools open and it is the case that education is a community competence, they agreed that teaching activities should be suspended by a federal ministerial decree.

When a second wave was looming in mid-July, measures were less drastic (Ministerial Decree of 10 July 2020). Shops, bars, and restaurants stayed open conditional on certain preventative measures; the wearing of face masks was obligatory in specific public places and shopping streets; dance halls, discotheques, wellness centres, and hammams were forbidden; people could gather only in groups of a maximum of 10 persons, with some exceptions; non-essential travel was allowed within the EU with the exception of 'red zones'; and close contact was limited to five persons per household. Some local authorities, at the municipal 
level as well as at provincial level used the opportunity provided by the ministerial decree to take additional measures to counter local surges of infections.

\subsubsection{Health-care measures}

Steps were taken to give health-care providers full capacity in terms of staff, infrastructure, and equipment. These included regulations on the sale, distribution, commissioning, and use of rapid self-tests, medical devices, personal protective equipment and biocides, and on the triage of potentially infected persons.

\subsubsection{Exit measures}

Exit measures enabled the relaxation of initial controls and reopening of business and other services. On 24 March 2020, the NSC announced a phased exit strategy that would begin in early May and gradually allow greater social and economic activity, including the phased reopening of schools (a community competence). In its decision-making, the NSC relied on the advice of the multidisciplinary expert group GEES. The measures followed one after the other at a surprisingly fast pace until, at the end of July, signs of a new outbreak forced the government to put further relaxations on hold and take a new set of preventative measures.

\subsubsection{Socio-economic measures}

Steps were also taken to mitigate the pandemic's socio-economic consequences. Among these were measures to support ('viable') firms by means of government guarantees for credit granted by credit institution, lower value-added tax (VAT) rates for restaurants, or subsidies for self-employed persons who were temporarily unable to pursue their activities. Employees could fall back on temporary unemployment relief, a system already in existence but now amended with simplified procedures and increased wages.

\subsubsection{Measures to mitigate other measures}

Measures were adopted to deal with the repercussions that preventative measures had for ongoing activities, obligations, and requirements. For instance, the functioning of essential services such as federal administrations and the national rail network had to be ensured, and measures put in place to discontinue or extend terms, for example in litigation procedures.

\subsubsection{Challenges in the council of state}

The special powers above were used mainly for type 5 measures and only occasionally for type 3 or 4 measures. Most type 4 measures were based on Acts 
of Parliaments, whereas all type 1 and 2 measures were issued by a ministerial decree. The ministerial decrees were challenged before the Council of State on several occasions. Within the period under review, the Council ruled on suspension requests only in urgent procedures and dismissed them all.

In these cases, it showed great reluctance to interfere with the government's crisis management. At first, it held that the Minister of Health has 'the widest discretion to fight an unprecedented and most serious international health crisis' (Council of State, No. 247.452 Stihl and Fedagrim, 27 April 2020, para. 30). This was not repeated when it came to the exit measures. Here, the government was given merely 'wide' discretion, but a duty of care was imposed on it which required that crisis measures do not depart from relevant facts, be established with care, and be weighed against all the interests at stake (Council of State No. 248.151 Vandonghen, 17 August 2020).

However, the Council referred to expert advice and consultation only as an aid to support the crisis measures - it accepted that the government took an even stricter position than what was recommended by experts (Council of State Nos. 248.131 BV The Masters, 10 August 2020; 248.132 BV Harman, 10 August 2020). In addition, when fairground stallholders criticised measures for being disconnected from the realities of their sector, the Council reiterated that the government was advised by expert committees but it did not examine whether in this instance the fairground sector had been consulted (Council of State No. 248.151 Vandonghen, 17 August 2020). The Council thus missed an opportunity to give the government guidance on how to balance safety concerns and fundamental rights.

\subsubsection{State action}

Actions by the communities and regions fell into the same five categories as did federal action.

- All three communities implemented the ministerial decrees by closing down primary and secondary schools within their respective jurisdictions and prohibiting visits in retirement homes.

- Regions simplified procedures for the construction and utilisation of infrastructure for medicines or medical equipment and activated emergency plans for hospitals. All levels of government (including some municipalities) simultaneously engaged in the procurement of medical supplies such as face masks and protective gowns.

- The communities implemented federal exit measures for those establishments within their sphere of competences, such as schools, museums, and residential care centres.

- The regions put in place a series of financial compensations and guarantee schemes for businesses that were closed or limited in operation, in addition to administering the federal temporary unemployment scheme for employees 
of these businesses. They also provided for rental price adjustments, subsidies for day-care, and the like.

- The regions guaranteed minimal public transport services by bus and tram and facilitated the extension of rental agreements. Regions and communities extended terms for ongoing administrative procedures and made arrangements for the functioning of administrations and other public services.

The Flemish and German-speaking communities took action mostly on the basis of specific legal authorisations. By contrast, the Walloon Region, the French Community, and the Brussels Region quickly adopted a Special Powers Act on the basis of which the governments made arrangements without prior parliamentary involvement and with the possibility to amend or bypass parliamentary acts. The scope of these special powers was unheard of; moreover, the parliaments of regions and communities that granted special powers had either adjourned or substantially reduced their activities (Bouhon et al. 2020).

We can conclude that the communities and regions were, to a large extent, the implementers of federal type 1 and 2 measures. At the same time, they were closely involved in the federal decision-making that led to these measures. Also, they had wide discretion to take measures in the other categories, within their sphere of competence. Interestingly, communities chose to coordinate their actions even where they had some policy discretion, for example in the reopening of schools. This was welcomed especially in Brussels, where both the French and Flemish communities have jurisdiction - indeed, it would have been difficult to explain why measures were more stringent in one (Francophone) school or cultural establishment than in a similar (Flemish) establishment around the corner.

Overall, the communities did not always give evidence of better crisis management than the central government. They were criticised in particular for slow progress in contact tracing, to the point that municipalities were eager to take over.

\subsubsection{Local government action}

The regions are responsible for local authorities; accordingly, regional governments inform and support local authorities. The 'federal phase' of crisis management implied the coordination of measures at the federal level and implementation and enforcement at the local level (municipalities and provinces). As a result, local entities predominantly played a role in the enforcement of type 1 measures; in regard to type 4 measures, they pledged to support local businesses.

In addition, the ministerial decree of 24 July 2020 allowed mayors and provincial governors to take measures in case of a local surge in infections. They had to notify the competent regional administration, as well as the provincial governor, who has a coordinating function. Mayors could, for instance, make it compulsory to wear face masks in crowded environments over and above the 
places already indicated in the ministerial decree. The latter stipulated that local measures were enforceable through criminal sanctions.

In one instance, the NSC called on the governor of the Province of Antwerp to take additional measures to address the deteriorating epidemiological situation in the province in the final weeks of July 2020. This resulted in the governor issuing an ordinance on 29 July that, among other things, made face masks mandatory in all public and publicly accessible places, changed the closing hours of bars and restaurants from 01:00 to 23:00, and imposed a curfew from 23:30. The latter was the most contested of these measures and was challenged before the Council of State. However, the petitions were rejected without a decision on their merits.

Several mayors of municipalities also took additional measures (for instance, in regard to closing hours of cafés and obligatory facemasks in public), depending on the epidemiological situation. They had police powers to act in urgent circumstances, but the measures had to be subsequently ratified by the city council. By stepping in in this way, local government showed its usefulness in addressing health crises, an observation which may inform future state reform.

\subsubsection{Intergovernmental relations: A virus-driven push for cooperation}

In Belgium, IGR usually take place in the Concertation Committee and inter-ministerial conferences and through cooperation agreements (Popelier 2021b). The central body is the Concertation Committee, which consists of the prime ministers and ministers from the federal and federated levels of authority. It is characterised both by linguistic parity (French-Dutch) and parity in federal and federated government representatives. The committee organises sectoral inter-ministerial conferences for the discussion of high-level policy issues such as state reform, the environment, or foreign policy, with these conferences often leading to cooperation agreements (Poirier 2002: 34).

Formal IGR is accompanied by informal IGR, which plays out mainly in interaction between the party elites of majority parties at different levels of government. Informal IGR functions as a mechanism for reducing conflict - before matters reach the Concertation Committee, they are usually addressed out of sight of the public eye and resolved among the governing party leaders or among ministerial cabinets (Poirier 2002: 34).

Belgium is designed as a fragmented, multinational, dyadic, and dual type of federalism where legislative as well as administrative powers are allocated on the basis of exclusivity. Transfers of powers to the communities and regions are the usual outcome of deadlock at the federal level, where antagonistic Flemish and French-speaking partners govern in a pseudo-confederal manner (Pas 2004: 160). Belgian dual federalism was therefore designed to prevent IGR as much as possible (Adam 2019: 591; Swenden and Jans Maarten 2006: 886).

At the same time, as mentioned, exclusivity entails fragmentation: policy fields are broken down into detailed dimensions and scattered over different 
levels of authority. As shown in a previous section, social and health policy, of crucial importance in the Covid-19 crisis, is one of these fragmented policy fields. Paradoxically, this fragmentation in turn forces the entities to cooperate and thus to engage in IGR.

Dual and dyadic federalism also explains the particular form that Belgian IGR takes, given that it is based on a multipolar playing field of federal and federated levels of authority but is also influenced by bipolar politics (Poirier 2002: 26). IGR in Belgium, as elsewhere (Swenden 2006: 190; Trench 2006: 227), is confined mainly to the executive level, where it takes place through negotiations in informal inter-ministerial consultations, inter-ministerial conferences, or formally in the Concertation Committee and through cooperation agreements concluded by the executives. IGR is thus easier when the ruling parties at the regional level are also coalition partners in the federal government.

Incongruent government formations, however, have become more common. During the Covid-19 pandemic, the federal minority emergency government in no way reflected the regional governments. In particular, the major political parties - the socialist party Parti Socialiste in the Walloon Region and French Community, and the nationalist party Nieuw-Vlaamse Alliantie in the Flemish Community - were not part of the federal coalition.

Intergovernmental relations, generally speaking, are dominated by federal governments (Trench 2006: 229), but this is not so in Belgium: even in regard to EU policies, where the federal level plays a coordinating and gatekeeping role, the regions and communities have become dominant role-players (Beyers and Bursens 2006: 1062). This poses a risk in that the absence of a dominant federal actor creates a bias towards the joint-decision trap, which can limit the effectiveness of governance (Trench 2006: 229); however, such IGR in the context of dual federalism may also engender a more integrated federalism.

In Belgium, this is particularly the case in matters that involve international decision-making. The intensity of intergovernmental cooperation and coordination has led scholars to argue that Belgium, in this arena, has moved towards cooperative federalism (Beyers and Bursens 2013: 277; Van den Brande 2012: 429).

Nonetheless, securing cooperation and compromise during the 2020 pandemic was an arduous task. This became clear when Belgium was the only EU member state that had to abstain when the Union responded to Covid-19 by mobilising funds from the European Structural and Investment Funds and making them available under cohesion rules. The reason was that the Flemish political party Nieuw-Vlaamse Alliantie argued that, under the logic of European cohesion policy, most of the funding to Belgium would go to the Walloon part, whereas the Flemish part was the most affected by the virus.

Initially, though, intergovernmental cooperation went surprisingly smoothly. As mentioned, there was consensus that the federal government should take the lead, with the NSC opening to involve the minister-presidents of the Communities and Regions. At press conferences, minister-presidents were 
seated prominently next to the Prime Minister to demonstrate intergovernmental accord. In addition, the governments could fall back on the protocol and institutions mentioned in section 3. This activated, inter alia, the RMG, with representatives from the federal and federated entities as well as the Interministerial Conference of Health.

The press conferences, however, followed long and difficult meetings that were held to reach compromise on thorny issues such as the shutdown of schools. Experts who participated in the decision-making complained about the innumerable committees and officials who were involved and the absence of leadership to take charge in the event of disagreement. Also, there was some competition in the purchasing of face masks and protective gear, with both the federal and community governments having placed orders. When contact tracing at the community level got off to a difficult start, the Flemish Minister of Welfare pointed a finger at deficient data inflow from the federal platform and unadjusted protocols for information-sharing, arguing that the Flemish system of contact tracing had been hampered by insufficient test capacity and appealing for the establishment of an intergovernmental committee and taskforce to solve the problem (Flemish Parliament 2019-2020). Likewise, local authorities complained about regional government failures in implementing track-and-trace policies, to the point that they threatened to install local systems.

As a result, prominent political actors put new state reforms on the agenda, albeit that they had differing views. Some advocated for the centralisation of crucial domains in order to combat future pandemics more effectively; others demanded even further decentralisation to avoid complex and slow decision-making. Experts and health-care workers, having dealt on the ground with the consequences of Belgium's complex system of governance, pleaded above all for unity of command, regardless of the direction future state reform takes.

\subsubsection{Intergovernmental fiscal relations}

Needless to say, the impact of the coronavirus crisis weighed heavily on the budgets of the federal, federated, and local entities. The National Bank predicted that the Belgian economy would suffer permanent damage and public finances be hit hard. The outlook for 2020 showed a decrease in gross domestic product (GDP) of 10 per cent per resident and sovereign debt - already burdensome before the crisis - rising to 120 per cent of the GDP, that is, twice as high as it would have been without the crisis (National Bank 2020). In addition, it was forecast that the budget deficit of the Belgian federation would rise to 6 per cent of GDP, the bulk of which would be shouldered by the federal level.

The financial capacity to carry the costs differed among the regions, with the Walloon Region being the poorest entity in terms of GDP and the Flemish Community the most prosperous. ${ }^{9}$ A fiscal equalisation programme was in place, with fees for the communities (with social and cultural competences) on the basis of need, and for the regions (with economy and territory-based competences) 
on the basis of performance. Still, the variation in wealth inevitably resulted in differing room for manoeuvre for regional subsidy mechanisms.

At the time of this writing, no changes to fiscal federalism principles were on the agenda. The new federal government agreement of 1 October 2020 entrusted only two federal ministers with the task of preparing a new state reform and gave little detail. Ultimately, however, a deal on future fiscal federalism mechanisms will have to be concluded. The differential impact of Covid-19 economic costs would undoubtedly complicate the operation of the new federal government with seven political parties on board.

\subsection{Findings and policy implications}

The core features of the Belgian federal system determine which actors and government levels come to the fore, how they respond, and how they interact. Among these features are an intricate division of powers, dual federalism with exclusive competences, vertical IGR, and a split party system. Moreover, incongruent government coalitions resulting from split electoral constituencies probably hindered cooperation and information exchange, although their precise impact is difficult to assess.

The most crucial finding is that, similar to what happened in the policy domain of EU and foreign affairs, the Covid-19 pandemic in Belgium was an external factor that reshaped de jure dual federalism into de facto cooperative federalism. The legal scheme of competence allocation was interpreted creatively. As a rule, matters are allocated on the basis of exclusivity, with the federal and federated entities situated as equal partners. By contrast, crisis management in 2020 was considered a federal competence cutting across exclusive community and region competences, contrary to previous Council of State opinions, and reducing the federated entities to implementers of federal policy. Only in a later phase, advising on a parliamentary Pandemic Act, did the Council of State (2021) develop a new theory to legitimize this situation, thereby fixing this behaviour for the future.

This occurred with the full agreement of the federal and federated authorities. While the federal level was put in charge, federal policies and decisions were made on the basis of intergovernmental cooperation and implemented by the federated entities whenever the policies and decisions applied to their competences. At the same time, intergovernmental cooperation and coordination lacked unity of command, resulting in slow, complex decision-making. Moreover, the absence of an adequate pre-existing legal framework for crisis management caused confusion and, particularly at the outset of the crisis, made decision-making onerous in a situation requiring speed of response.

Another finding is the rise of local authorities as relevant actors in the Belgian multi-tiered system. Initially mere enforcers of federal measures, they gained a more prominent position at the start of the second wave of infections when 
granted the power to enact additional measures in a system of differentiated crisis management; they also established partnerships when the Flemish contact tracing system proved deficient. In a later phase, they would also contribute to a successful vaccination campaign. The appearance on the scene of local authorities is quite remarkable. The successive state reforms of the last 50 years were designed to mitigate adversarial relations between regional entities and resulted in decentralisation to the regional level. The Covid-19 health crisis revealed, however, that the designers of Belgian federalism neglected the potential contribution of a level further down - local government - not only in the implementation but the design of public policies.

The pandemic triggered calls for institutional reform, especially regarding the division of competences in public health policies. The new government agreement envisaged a new state reform in 2024. In all likelihood, the reforms will be based less on an evaluation of how the Covid-19 crisis was managed than on the interests and demands of the parties that formed the new federal government. Despite the uncontested centralist approach to crisis management, the crisis did not appear to have enhanced Belgium's federal 'esprit'. The Flemish-nationalist Nieuw-Vlaamse Alliantie put on the table proposals for a further decentralising state reform. The party was not a member of the new government, but as the major Flemish political party it was very likely to influence the position of the coalition partners. Also, its support would be crucial for the next state reform, considering the special majority requirements.

Demands for further decentralisation, especially in the domain of health policy, were also voiced by the coalition partner, the CD\&V (Christen-Democratisch en Vlaams). The precarious financial position of the French-speaking entities stood to facilitate such a development, as a deal would imply federal financing yet regional policy autonomy, the latter being favoured as well by the Parti Socialiste, the dominant French-speaking player.

Whether such an outcome would be sustainable in the light of an already ailing federal level seems doubtful. Moreover, decentralisation will not obviate the crucially important need for cooperation should Belgium be hit by another pandemic. One reason is that a pandemic cuts across a wide range of policy domains; another is that, considering the density of the Belgian population, crisis management in one region inevitably impacts on that in another - all the more so in the case of Brussels, where communities have overlapping competences.

The architects of a seventh state reform thus have the responsibility to provide clarity on the allocation of competences and to develop clear and efficient schemes for coordination, cooperation, and lines of command in crisis management policies. Preferably, the local level should be factored in too. Belgium's experience in 2020 shows that crisis management should combine, on the one hand, a centralist approach with unity of command and, on the other, a differentiated approach respecting and utilising the autonomy of the regional and community level as well as local authorities. 


\section{Notes}

1 The headline in La Libre Belgique read, 'La Fracture'; in L'Echo, 'La Belgique coupée en deux'; in La Capitale, 'La fin de la Belgique'; and in Le Soir, 'Deux Belgiques'.

2 For epidemiological data, see Sciensano (2020).

3 For an overview of the allocation of competences relevant to the Covid-19 pandemic, see Van Nieuwenhove and Popelier (2021).

4 See Council of State, Legislative Branch Opinion No. 67.423/3 of 26 May 2020; Opinion No. 67.425-427 of 26 May 2020.

5 See Council of State, Legislative Branch Opinion 47.062/1/V of 18 August 2009; Opinion 53.018/VR of 13 May 2013; Opinion 53.932/AV of 27 August 2013.

6 The mandate of these three bodies also applies in case of health threats of national concern.

7 Protocol to establish the generic structures for sectorial health management of crises for public health and their method for the implementation of the International Health Regulation (2005) and Decision No. 1082/2013/EU on serious cross-border threats to health of 5 November 2018', Official Gazette 14 December 2018 (Protocol 2018).

8 Council of State. 2020. Opinion No. 67.423/3 of 26 May 2020.

9 See https://www.statistiekvlaanderen.be/nl/bruto-binnenlands-product-per-inwoner-0 (after factoring in the commuting component to Brussels Capital).

\section{References}

Adam, Ilke. 2019.'Defying the Traditional Theses: Intergovernmental Relations on Immigrant Integration in Belgium', Regional \& Federal Studies, 29(5): 591-612.

Andries, Simon. 2020. 'Ik heb te veel absurditeiten gezien. Ons systeem werkt niet', De Standaard 30 May.

Beyers, Jan and Peter Bursens. 2006. 'The European Rescue of the Federal State: How Europeanisation Shapes the Belgian State', West European Politics, 29(5): 1057-78.

Beyers, Jan and Peter Bursens. 2013. 'How Europe Shapes the Nature of the Belgian Federation: Differentiated EU Impact Triggers Both Co-operation and Decentralization', Regional \& Federal Studies, 23(3): 271-91.

Bouhon, Frédéric et al. 2020. L'Etat belge face à la pandémie de Covid-19: esquisse d'un régime d'exception', Courier Hebdomodaire Crisp No. 2446.

Council of State. 2021. Advice 68.936/AV of 7 April 2021.

EU Decision 2013. Decision No. 1082/2013/EU of the European Parliament and the Council of 22 October 2013 on Serious Cross-Border Threats to Health, Official Journal 5 November 2013, L293/1.

Flemish Parliament (2019-2020). Commission Report. No. 289/5, 23, 24.

Happaert, Sander, Simon Schunz and Hans Bruyninckx. 2012. 'Federalism and Intergovernmental Relations: The Multi-Level Politics of Climate Change Policy in Belgium', Journal of Contemporary European Studies, 20: 441-58.

National Bank. 2020. 'The Belgian Economy's Recovery from the Coronavirus Crisis will be Difficult', https://www.nbb.be/en/articles/belgian-economys-recovery-coronaviruscrisis-will-be-difficult-and-budget-deficit-2022-will (accessed on 1 December 2020).

Pas, Wouter. 2004. 'A Dynamic Federalism Built on Static Principles: The Case of Belgium', in G. Alan Tarr, Robert F. Williams and Joseph Marko (eds), Federalism, Subnational Constitutions, and Minority Rights. Westport: Praeger.

Poirier, Johanne. 2002. 'Formal Mechanisms of Intergovernmental Relations in Belgium', Regional \& Federal Studies, 12(3): 24-54. 
Popelier, Patricia 2020a. 'COVID-19 Legislation in Belgium at the Crossroads of a Political and a Health Crisis', TPLeg, 8(1-2): 131-53.

Popelier, Patricia. 2020b. 'Crisisbeheer bij Ministerieel Besluit', Tijdschrift voor Wetgeving, 23(4): 282-291.

Popelier, Patricia. 2021a. 'Exclusive Powers and Self-Governed Entities: A Tool for Defensive federalism?', in Ferran Requejo and Marc Sanjaune (eds), Defensive Federalism. Routledge (forthcoming).

Popelier, Patricia. 2021b. 'Intergovernmental Relations in Belgium: Obstacles for Effective Cooperation in Dyadic Federalism', in Yonatan Fessha, Francesco Palermo and Karl Kössler (eds), Intergovernmental Relations (forthcoming).

Sciensano. 2020. https://datastudio.google.com/embed/u/0/reporting/c14a5cfc-cab74812-848c-0369173148ab/page/QTSKB (accessed on 1 December 2020).

Swenden, Wilfried. 2006. Federalism and Regionalism in Western Europe: A Comparative and Thematic Analysis. Basingstoke and New York: Palgrave Macmillan.

Swenden, Wilfried and T. Jans Maarten. 2006. 'Will It Stay or Will It Go? Federalism and the Sustainability of Belgium', West European Politics, 29(5): 877-94.

Trench, Alan. 2006. 'Intergovernmental Relations: In Search of a Theory', in Scott L. Greer (ed.), Territory, Democracy and Justice: Regionalism and Federalism in Western Democracies. Basingstoke and New York: Palgrave Macmillan.

Van den Brande, Karoline. 2012. 'Intergovernmental Co-operation for International Decision-making in Federal States: The Case of Sustainable Development in Belgium', Regional \& Federal Studies, 22(4): 407-433.

Van Nieuwenhove, Jeroen and Patricia Popelier. 2021. De bevoegdheidsverdeling en de coördinatie tussen de bevoegde overheden in de strijd tegen de Covid-19 pandemie, Tijdschrift voor Wetgeving (forthcoming).

Vanheule, Dirk. 2020. 'Reizen in tijden van corona. Een lockdown van en aan de grenzen?', Rechtskundig Weekblad 1448.

Wilmès, Sophie. 2020. Prime Minister Wilmès, Questions Plenary Session, Question 9, Integral Report, House of Representatives 9 April, afternoon session, CRIV 55 PLEN 035 . 